\title{
Publish in English, or perish?
}

\section{Paris}

A FrenCH scientist claims that he was denied promotion within the country's largest research organization because none of his work had been published in English. His accusation has reopened a debate between the country's research establishment, which maintains that English is the new international language, and cultural and political forces that are trying to prevent further erosion of the status of their mother tongue.

The unlikely figure at the centre of this debate, which extends into the presidential palace, is Claude Roux, a lichenologist at the Mediterranean Institute of Ecology and Palaeoecology at the Faculty of Science and Technology at Saint-Jerome, Marseille. For the past two years, Roux has applied for promotion to the level of director of research at the Centre National de la Recherche Scientifique (CNRS). He was one of 40-50 scientists who had applied each year for eight such positions.

After his second unsuccessful attempt, Roux says that a member of the jury, Jacques Balandreau of the Institut de l'information scientifique and technique (INIST) in Nancy, told him that "your dossier is very good, but you have no chance of being retained because you have not published in English". The confidential report on Roux's application makes no reference to this as a reason for his unfavourable recommendation.

Roux claims his case is part of a pattern by the CNRS to pressure its scientists into publishing in English. "The CNRS message is very clear - you have no future unless you publish in English." In February, Roux says, the president of the CNRS Commission visited his laboratory and "recommended that we associate with an Anglophone author, for the purposes of publication, even if his role was essentially limited to that of a translator."

The Haut Conseil de la Francophonia, a committee under the patronage of French President François Mitterand, has taken up Roux's cause. In its reply to a letter from Roux, the council does not claim to know the true reason for the CNRS decision but nevertheless warns against "cultural alienation", adding that "we have without doubt no need to use English to contribute to the advancement of science."

In 1989, there was a national outcry when the Pasteur Institute decided to publish its journals in English. It was seen as a belated reaction to a trend within the scientific community to converse in English. This is particularly the case in such fast growing fields as molecular biology, but less so in the area in which Roux works.

The president of the jury that evaluated Roux, Robert Barbault of the University of Paris VI, believes that the CNRS posi- tion on the importance of English makes perfect sense. "Researchers are not only there to work, but also to diffuse their discoveries", he says. "This diffusion is most efficient if it is via widely read journals, that is in English. Publishing in English not only promotes French science abroad, but also draws attention to other published works in French. To advise a candidate for the post of director of research to make an effort to publish in English is the logical consequence of this."

Leaving aside Roux's case, some French scientists say that the government needs to enforce a clear, consistent policy on the subject of using French in their work. In a letter to Mitterand, Marcel Barbero of the Faculty of Sciences at Marseilles states "we can no longer accept that the governing boards of the national research organisations, despite the declarations of the Head of State, the government and the ministries, continue to ignore French as an international language of communication and expression in science." He says that the CNRS no longer subsidises scientific journals in French, and that even CNRS conferences held in France are conducted in English.

The CRNS has ignored these directives "because it is more in touch with the scientific realities", says Barbault. "Conferences have to be held in English, and even when we ask the government for cash for translation facilities they don't give it." Roux says such CNRS policies are nonsense, especially when applied to a small field such as lichenology, where "publication in English is not really a consideration".

Whether Roux was qualified for the promotion is, of course, difficult to know. Says Barbault, "not all researchers have the opportunity to direct a team. The job calls for more than just being a good researcher. You have to be an animator and a leader, too."

A similar ambiguity exists when trying to compare the quality of Roux's French publications with comparable publications in English-language journals. Balandreau says that "I simply told him that, if you want to increase your chances [of promotion], you must publish in English-language journals which are peer-reviewed. Roux has a large number of articles, but they are mostly in provincial publications."

Roux disputes that statement. Of 97 publications, 24 of them in the past three years, he says that 15 have appeared in CNRS class-A peer-reviewed international journals ( 8 French, 7 foreign); 4 in other foreign peer-reviewed journals with a majority of foreign participation; 41 in French journals with peer-review boards composed mainly of foreign scientists; and 31 in other French peer-reviewed journals. Roux says the CNRS is wrong to place a higher value on non-peer-reviewed journals in English than in peer-reviewed French journals.

Whatever the outcome of the Roux case, the government now seems ready to take action. This month, the high council decided that publication of scientific reviews and educational works in French should be a criterion in the evaluation of researchers. It also announced plans to start a European multilingual peer-reviewed journal along the lines of Nature and Science. The proposed journal, which is expected to contain a substantial portion of articles in French, has apparently received support from the European Community. Other possibilities include a multilingual Science Citation Index and a council office in New York to complement the existing one in Geneva.

David Bakewell

\section{AIDS THERAPIES}

\section{Kemron's secret: it doesn't work}

\section{Washington}

EVER since a Kenyan researcher took the results of an uncontrolled clinical trial to mean that a dilute oral alpha interferon solution (known as Kemron) could halt AIDS, rumours of an 'African AIDS cure' have run rampant. Now the US National Institutes of Health's AIDS Research Advisory Committee (ARAC) has examined preliminary results from 13 independent studies and come to an unsurprising result: Kemron does not work.

In a statement to be released this week, the ARAC says that no independent trials to date have replicated the Kenyan results. The committee strongly recommends that patients now taking Kemron seek alternatives. At its 31 March meeting, the committee examined preliminary data from a World Health Organization review of 13 trials of the drug. The trials failed to confirm the seroconversion and increased CD4 cell counts that the researchers from Kenya Medical Research Institute had originally reported.

None of this, however, is likely to stop the rumours and conspiracy theories. Last month a science adviser for Jerry Brown, the US presidential candidate, said that investigating Kemron would be one of Brown's priorities. And the Gay Men's Health Crisis (GMHC) in New York says it still gets "an amazing" amount of inquiries about the drug.

The African-American press has alleged that negative reports from clinical trials are a plot to suppress the drug, and Kemron is still sold on the US black market and in Kenya.

Christopher Anderson 